\title{
EFFECT OF THE NORTH ATLANTIC OSCILLATION ON ICE PHENOMENA ON SELECTED LAKES IN POLAND OVER THE YEARS 1961-2010
}

\author{
Dariusz WrZesińsKi, Mariusz PtaK, Alicja BaczyńsKa
}

Institute of Physical Geography and Environmental Planning, Adam Mickiewicz University in Poznań, Poland

Manuscript received: September 21, 2012

Revised version: June 8, 2013

\begin{abstract}
WrZesiński D., PTAK M., BAczyńsKa A., 2013. Effect of the North Atlantic Oscillation on ice phenomena on selected lakes in Poland over the years 1961-2010. Quaestiones Geographicae 32(3), Bogucki Wydawnictwo Naukowe, Poznań, pp. 119-128. 5 tables, 3 figs. DOI 10.2478/quageo-2013-0020, ISSN 0137-477X.
\end{abstract}

Abstract: An analysis is presented of changes in the parameters of ice phenomena on selected Polish lakes over the years 1961-2010 against the background of variations in the intensity of the North Atlantic Oscillation. The following features were analysed: the start and end of ice phenomena and ice cover, their duration, and the stability of ice cover at observation sites of the Institute of Meteorology and Water Management on lakes located in various physical-geographic regions. Multi-year tendencies of change in the ice parameters under study were identified. The most statistically significant negative trends were observed for the ending dates of ice phenomena and their duration. Changes in the ice characteristics in the different $\mathrm{NAO}_{\mathrm{DJFM}}$ stages were determined on the basis of their deviations: between years with high (> 1.7) and low (<-1.09) values of the winter NAO index, and from average values from the years 1961-2010. Changes in the intensity of the North Atlantic Oscillation affect all the parameters of ice phenomena except their starting dates. In a negative $\mathrm{NAO}_{\mathrm{DIFM}}$ stage, ice phenomena and ice cover end later and last longer; also, the maximum thickness of ice cover is greater, its forms later and is more stable than in a positive stage and in average conditions.

KeY WORDs: lake, ice phenomena, trends, North Atlantic Oscillation, Poland

Address of the corresponding author: Dariusz Wrzesinski, Institute of Physical Geography and Environmental Planning, Adam Mickiewicz University in Poznań, Dzięgielowa 27, 61-680 Poznań, Poland; e-mail: darwrze@amu.edu.pl

\section{Introduction}

A characteristic feature of lakes of the temperate zone is the occurrence of ice phenomena, or the presence of any form of ice in water (frazil, shoreline ice, floe, ice cover). Of the greatest significance for the operation of lakes in the winter half-year is a compact ice cover, which isolates water masses from external factors. It totally eliminates the effect of wind with its generation of waves and currents, and substantially reduces or excludes solar radiation (depending on the ice structure and the presence/absence of a snow layer). This in consequence may lead to serious oxygen deficits dangerous to aquatic organismsso-called winter anoxia (Choiński, Ptak 2012). Besides, lake ice is treated as an indicator of global climate change (Marszelewski, Skowron 2006). Lake ice has long been a subject of many studies (Clifton 1875, Grześ 1974, Pasławski 1982, Górniak, Pękala 2001, Skowron 2003, Choiński et al. 2006, and other) which largely focus on dates of its occurrence and an assessment of the causes. The most substantial body of information about 
ice phenomena on Poland's lakes can be found in Skowron (2011), where 1976-2005 data are presented for 57 lakes.

There are three kinds of interlocking factors controlling the occurrence of ice phenomena: climatic conditions (inflow and stagnation time of different air masses), lake parameters (area, mean depth, exposure index), and human impact (inflow of wastewater, discharges of heated water). The last two factors are individual in nature and can result in different conditions of the appearance and duration of ice even in the case of close-lying lakes. They modify the first, climatic factor, which creates similar conditions of ice formation at a regional scale. Thus, an analysis of lacustrine ice phenomena requires as close an examination of those factors as possible, especially if they tend to change under the influence of macro-scale types of circulation, among which the North Atlantic Oscillation (NAO) is of particular significance in Poland.

The North Atlantic Oscillation is a bipolar type of atmospheric circulation with centres over Iceland and the Azores. The period when a big difference in pressure between the Azores High and the Icelandic Low can be observed is termed a positive stage of $\mathrm{NAO}_{\mathrm{DJFM}}$. This macro-scale type of circulation plays a very important, climate-forming role also in Poland (Marsz, Żmudzka 1999, Marsz 2001). It has been found to have a strong effect on the increase in temperature in the cold season of the year (Marsz, Styszyńska 2001, Kożuchowski, Degirmendžić 2002, Niedźwiedź 2002, Przybylak et al. 2003) on radiation and humidity conditions (Bryś, Bryś 2002), on precipitation conditions (Styszyńska 2001, Wibig 2001), and on the duration and thickness of snow cover (Falarz 2007, Bednorz 2009). There have been many studies documenting the effect of the North Atlantic Oscillation on the ice regimes of rivers and lakes. In the years with a positive $\mathrm{NAO}_{\text {DJFM }}$ index, ice cover disappears from rivers and lakes markedly earlier in northern Europe (Yoo, D'Odorico 2002), in the Alpine region (Livingstone 1997, Livingstone, Dokulil 2001), and in Poland (Girjatowicz 2003, Marszelewski, Skowron 2006, Choiński et al. 2009).

This article presents the characteristics of ice phenomena for three lakes in south-western, central and north-eastern parts of Poland (Fig. 1),

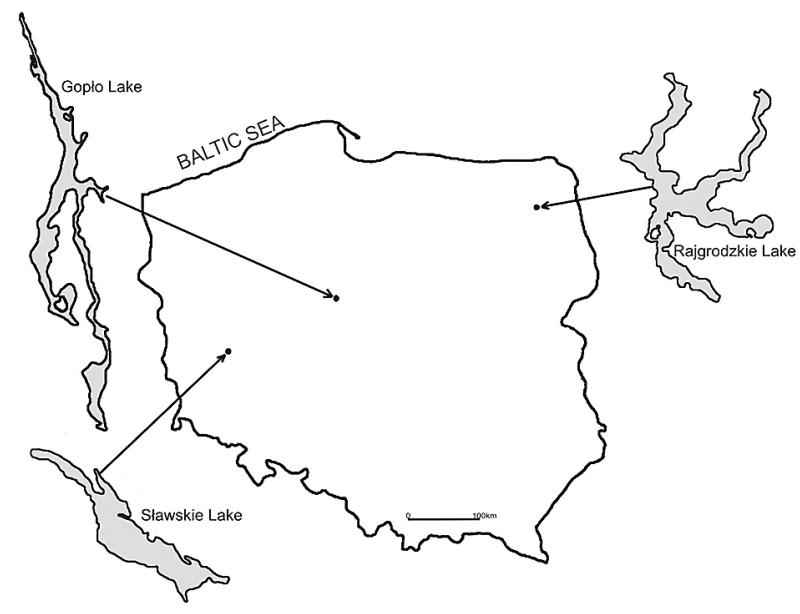

Fig. 1. Location of the study lakes

their multi-year tendencies of change, and the relation with $\mathrm{NAO}_{\mathrm{DJFM}}$ in the period 1961-2010, so far not analysed for Polish lakes.

\section{Source materials and the study objects}

The choice of lakes was dictated by the availability of information about ice phenomena collected and published by the Institute of Meteorology and Water Management (IMGW) in its Hydrological Yearbooks until the year 1983, and later archived in the Central Hydrological Database. Use was also made of Hurrell's winter $\mathrm{NAO}_{\text {DJFM }}$ index (Hurrell 1995) ${ }^{1}$.

The IMGW observation network has been reorganised many times over the years, regrettably producing a lot of gaps in the data. As a result, the longest observation series (1961-2010) concerns the lakes Sławskie, Gopło and Rajgrodzkie. The distance between the water bodies that are farthest apart exceeds $500 \mathrm{~km}$. The basic characteristics of the study objects are listed in Table 1.

\section{Methods}

Out of the many methods employed to detect changes in the time series of hydrometeorological variables (Radziejewski, Kundzewicz 2002), use

Updates: http://www.cgd.ucar.edu/cas/jhurrell/nao. stat.winter.html. 
Table 1. Morphometric data of the lakes

\begin{tabular}{|c|c|c|c|c|c|}
\hline Lake & $\begin{array}{c}\text { Area }^{1} \\
{[\text { ha] }}\end{array}$ & $\begin{array}{l}\text { Depth max } \\
\text { [m] }\end{array}$ & $\begin{array}{l}\text { Depth } \\
\text { average } \\
\text { [m] }\end{array}$ & $\begin{array}{l}\text { Volume } \\
\text { [thous. } \mathrm{m}^{3} \text { ] }\end{array}$ & $\begin{array}{l}\text { Exposure index } \\
\text { (Area/depth } \\
\text { average) } \\
{[\mathrm{ha} / \mathrm{m}]}\end{array}$ \\
\hline Sławskie & 822.5 & 12.3 & 2.4 & $42,664.8$ & 342 \\
\hline Gopło & $2,121.5$ & 16.6 & 3.6 & $78,497.0$ & 589 \\
\hline Rajgrodzkie & $1,499.0$ & 52.0 & 9.4 & $142,623.2$ & 159 \\
\hline
\end{tabular}

${ }^{1}$ Choiński (2006)

${ }^{2}$ Institute of Inland Fisheries (after Choiński 2006)

was made of linear regression and the non-parametric Mann-Kendall test.

To find the dependence of ice characteristics on the intensity of the North Atlantic Oscillation, Pearson's linear correlation coefficient $(r)$ was calculated.

Coefficients of correlation between standardised variables of ice phenomena $\left(Z_{\mathrm{ij}}\right)$, and Hurrell's winter $\mathrm{NAO}_{\mathrm{DJFM}}$ index $\left(Z_{\mathrm{ik}}\right)$ were calculated. An assessment of the statistical significance of the correlation coefficients was performed with the help of $t$ statistic:

$$
t=\frac{r \sqrt{n-2}}{\sqrt{1-r^{2}}}
$$

$t$ statistics has Student's distribution with $n-2$ degrees of freedom.

Changes in the ice parameters of the studied lakes in the different $\mathrm{NAO}_{\mathrm{DJFM}}$ stages were determined on the basis of differences between the values of those features in the given stages and between them and the mean figures from the years 1961-2010.

The means of the ice parameters were calculated for years with high $(>1.7)$ and low $(<-1.09)$ values of the winter $\mathrm{NAO}_{\mathrm{DIFM}}$ index. Those figures correspond to the first and third quartiles of the entire set of $\mathrm{NAO}_{\mathrm{DJFM}}$ indices for the years 1961-2010.

The statistical significance of those differences were examined using the $t$ test for independent samples. Tested each time was the hypothesis $\mathrm{H}_{0}: \mu_{1}=\mu_{2}$ about the equality of expected values against $H_{1}: \mu_{1} \neq \mu_{2}$. The rejection of the hypothesis allows a conclusion about significant differences in the mean values of ice parameters observed in the different $\mathrm{NAO}_{\mathrm{DJFM}}$ stages. $\mathrm{T}$ statistic has Student's distribution with $n_{1}+n_{2}-2$ degrees of freedom:

$$
T=\frac{\bar{X}_{1}-\bar{X}_{2}}{S_{\bar{X}_{1}-\bar{X}_{2}}}
$$

where is equal to: $S_{\overline{\mathrm{x}} 1-\overline{\mathrm{X}} 2}$

$$
S_{\bar{X}_{1}-\bar{X}_{2}}=\sqrt{\frac{\left(n_{1}-1\right) \cdot S_{1}^{2}+\left(n_{2}-1\right) \cdot S_{2}^{2}}{n_{1}+n_{2}-2} \cdot\left(\frac{1}{n_{1}}+\frac{1}{n_{2}}\right)}
$$

where $n_{1}, n_{2}$ - size of samples, $S_{1}{ }^{2}, S_{2}{ }^{2}$ - sample variances, $\bar{X}_{1}-\bar{X}_{2}-$ means from a sample.

\section{Results and discussion}

The analysis embraced the start and end of ice phenomena and ice cover, their duration, maximum ice cover and the date of its appearance (recorded since 1971), and ice cover stability (the number of days with ice cover against the number of days between the first and last day with ice cover) (Table 2).

When examining all the ice parameters, one can note differences largely determined by the location of the lakes in question. The differences between the mean parameters of Gopło are slight, unlike Lake Rajgrodzkie, where one can observe a later decay of ice cover and ice phenomena, the greatest thickness of ice, a longer duration of ice cover, and its greatest stability. What differentiates this water body from the other lakes is a later starting date of ice phenomena and ice cover, despite its location in the north-eastern part of Poland with its more continental climate, viz. more severe and longer winters. The reasons should be sought in the morphometric properties of Lake Rajgrodzkie. Its volume much exceeds those of the other two lakes, its mean depth is greater, and its exposure index smaller. One of the characteristic features of lakes is their great capacity to 
Table 2. Ice parameters

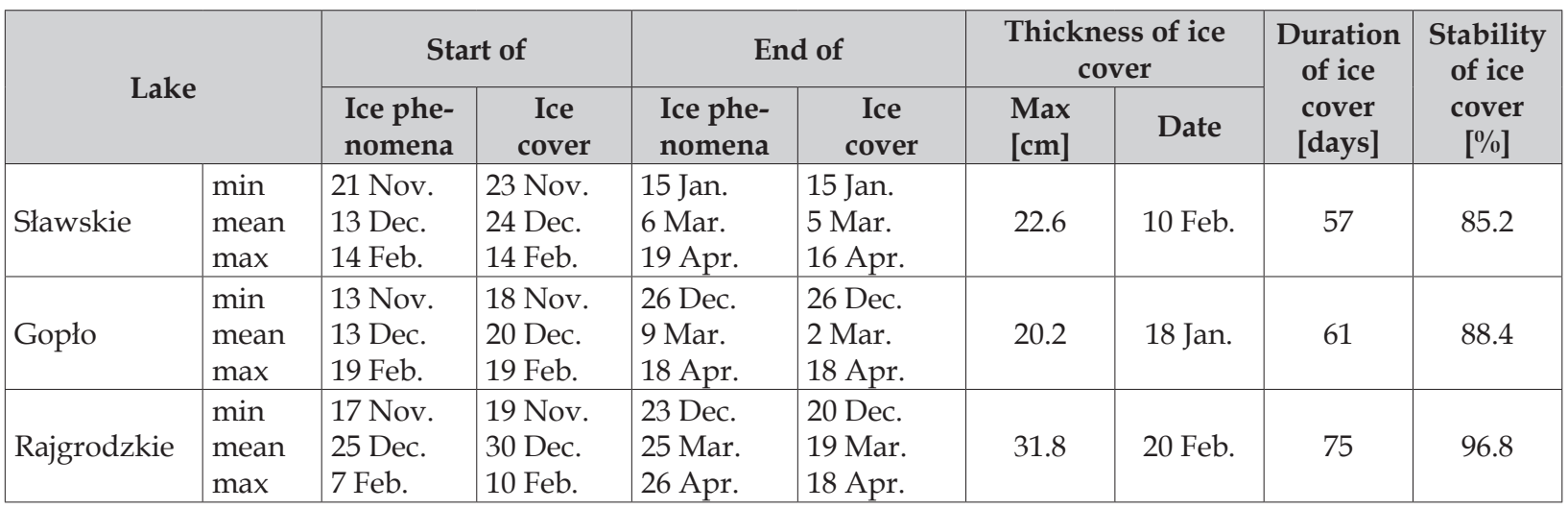

accumulate energy which is then released to the environment at different rates. Large and deep lakes emit warmth much longer than shallower ones (Choiński 2007). As has been observed by Marszelewski and Skowron (2009), in shallower lakes ice phenomena may appear even up to 10 days earlier than in deep lakes situated nearby (because of the latter's greater warmth reserves). In Lake Rajgrodzkie, the greater water mass capable of absorbing larger amounts of solar energy in the warm half-year releases it longer when it passes into the stage of autumn homothermy, which detains the appearance of inverse winter stratification and ice phenomena.

The analysis of multi-year tendencies of change in the values of ice parameters of the three lakes was based on the results of linear regression and the Mann-Kendall test (Table 3).

The dates of the start of ice phenomena and the appearance of ice cover do not vary greatly. While on Gopło and Lake Rajgrodzkie they appear ever earlier and on Lake Sławskie ever later, those changes are not statistically significant. More significant tendencies can be observed in the case of the end of ice phenomena and ice cover: on all the lakes their disappearance takes place ever earlier. Lakes Sławskie and Gopło show negative trends in the ending dates of ice phenomena; they are even statistically significant $(p<0.05)$. Also statistically significant $(p<0.05)$ are the trends in the dates of ice-cover decline on Gopło and Rajgrodzkie (Fig. 2, Table 3).

The ever earlier dates of ice decay also cause the duration of ice phenomena and ice cover to show a downward tendency, but it is statistically significant only in the case of the duration of ice phenomena on Lake Sławskie (Fig. 3, Table 3).
Over the study period, the ice-cover stability index also tended to go down, but a statistically significant downward trend $(p<0.05)$ in this parameter can only be observed on Lake Gopło (Table 3).

The maximum thickness of ice cover on the lakes under study also displays a downward tendency, and for Lake Rajgrodzkie this is a statistically significant trend $(p<0.05)$. Statistically insignificant, in turn, are changes in the dates when the maximum thickness occurs, even though in the case of lakes Gopło and Rajgrodzkie it can be seen to appear ever earlier.

Among the chief factors controlling the date of occurrence of ice phenomena are weather conditions in the winter season. In Poland those conditions largely depend on the intensity of a macro-scale type of circulation like the North Atlantic Oscillation. Hence an analysis was made of the correlation between the ice parameters under study and NAO intensity in winter (Table 4).

The calculated coefficients show strong, statistically significant correlations among the examined changes. In all the three lakes they concern the ending dates of ice phenomena and ice cover, their duration, and the maximum ice-cover thickness $(p<0.001)$. Negative trends can also be observed in the date of ice cover attaining its maximum thickness and in its stability index $(p<0.05)$. It is only in the case of the date of occurrence of the maximum ice-cover thickness on lake Gopło and ice-cover stability on Lake Rajgrodzkie that the observed negative trends are statistically insignificant.

The correlation between the ice parameters and the intensity of $\mathrm{NAO}_{\mathrm{DJFM}}$ is corroborated by changes in those parameters in the different $\mathrm{NAO}_{\mathrm{DJFM}}$ 
Table 3. Results of the analyses of multi-year tendencies in ice parameters

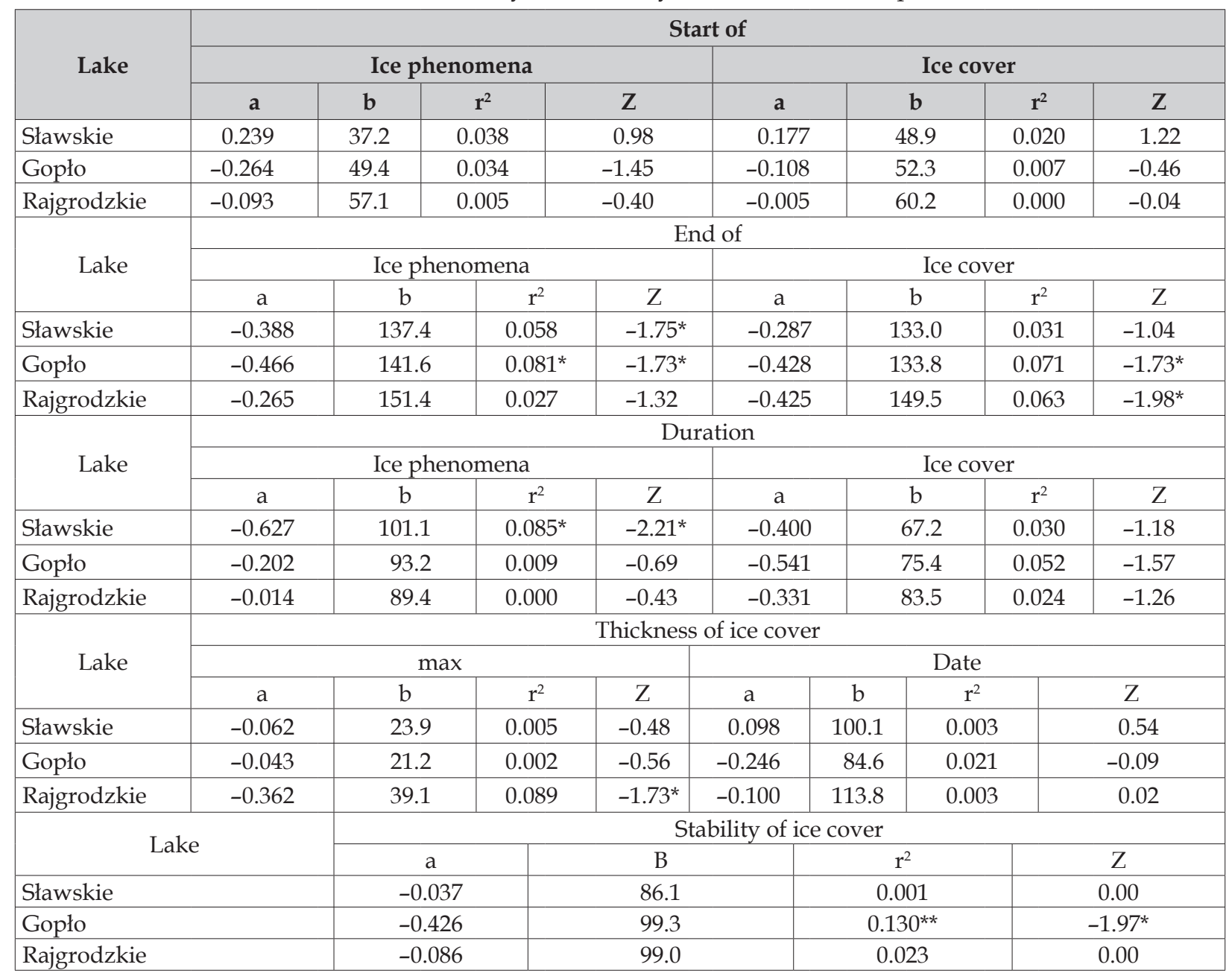

$\mathrm{a}$ - regression coefficient, $\mathrm{b}$ - absolute term, $\mathrm{r}^{2}$ - coefficient of determination; regression significant at: ${ }^{*} \mathrm{\alpha}=0.05,{ }^{* *} \mathrm{\alpha}=0.01,{ }^{* * *} \mathrm{\alpha}=0.001$ levels $\mathrm{Z}$ - Mann-Kendall test, trend significant at: ${ }^{*} \alpha=0.05,{ }^{* *} \alpha=0.01,{ }^{* * *} \alpha=0.001$ levels

stages, and between the stages and the average conditions from the years 1961-2010 (Table 5).

The differences are relatively minor in the case of the starting dates of ice phenomena and ice cover. Ice phenomena begin earlier, just under 10 days, in a negative $\mathrm{NAO}_{\mathrm{DJFM}}$ stage, and ice cover appears just under 2 days earlier than in its positive stage. However, the differences are marked (and highly significant statistically, $p<$ 0.001 ) in the ending dates of ice phenomena and ice cover: on all the lakes under study, in a negative $\mathrm{NAO}_{\mathrm{DJFM}}$ stage they come more than a month later (Table 5).

The differences in the ending dates of ice phenomena in the different $\mathrm{NAO}_{\mathrm{DJFM}}$ stages are slighter and statistically less significant when seen against the average conditions. In a negative stage, ice phenomena end up to 20 days lat- er than on average on lake Gopło. The observed differences are even statistically significant $(p<$ 0.05). In a positive stage, in turn, the ending dates are markedly earlier than under the average conditions, about 20 days again, and also statistically significant $(p<0.05)$.

Very wide differences can also be observed in the duration of ice in the different $\mathrm{NAO}_{\mathrm{DJFM}}$ stages. The greatest concern lakes Sławskie and Gopło, covered by ice 2 months longer in a negative than in a positive stage $(p<0.001)$. In turn, in a negative stage ice cover lasts on those lakes a month longer than the average for the years 1961-2010 $(p<0.05)$. And inversely, ice cover lasts a month shorter than on average in the years of great $\mathrm{NAO}_{\text {DIFM }}$ intensity $(p<0.01)$. Smaller, but also statistically significant differences can be observed on Lake Rajgrodzkie, located in north-eastern Po- 

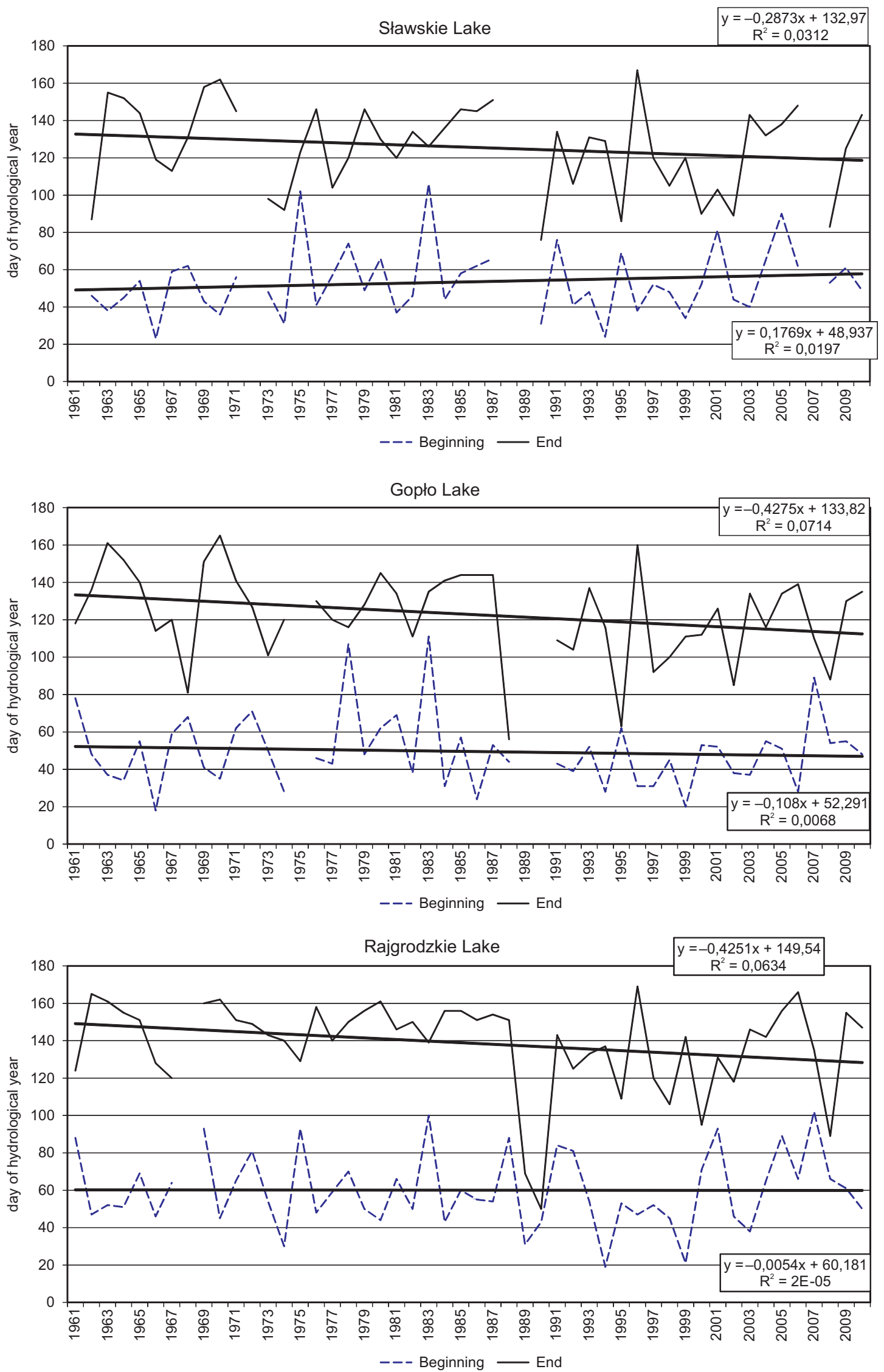

Fig. 2. Tendencies of change in the start and end of ice cover 
Duration of ice cover

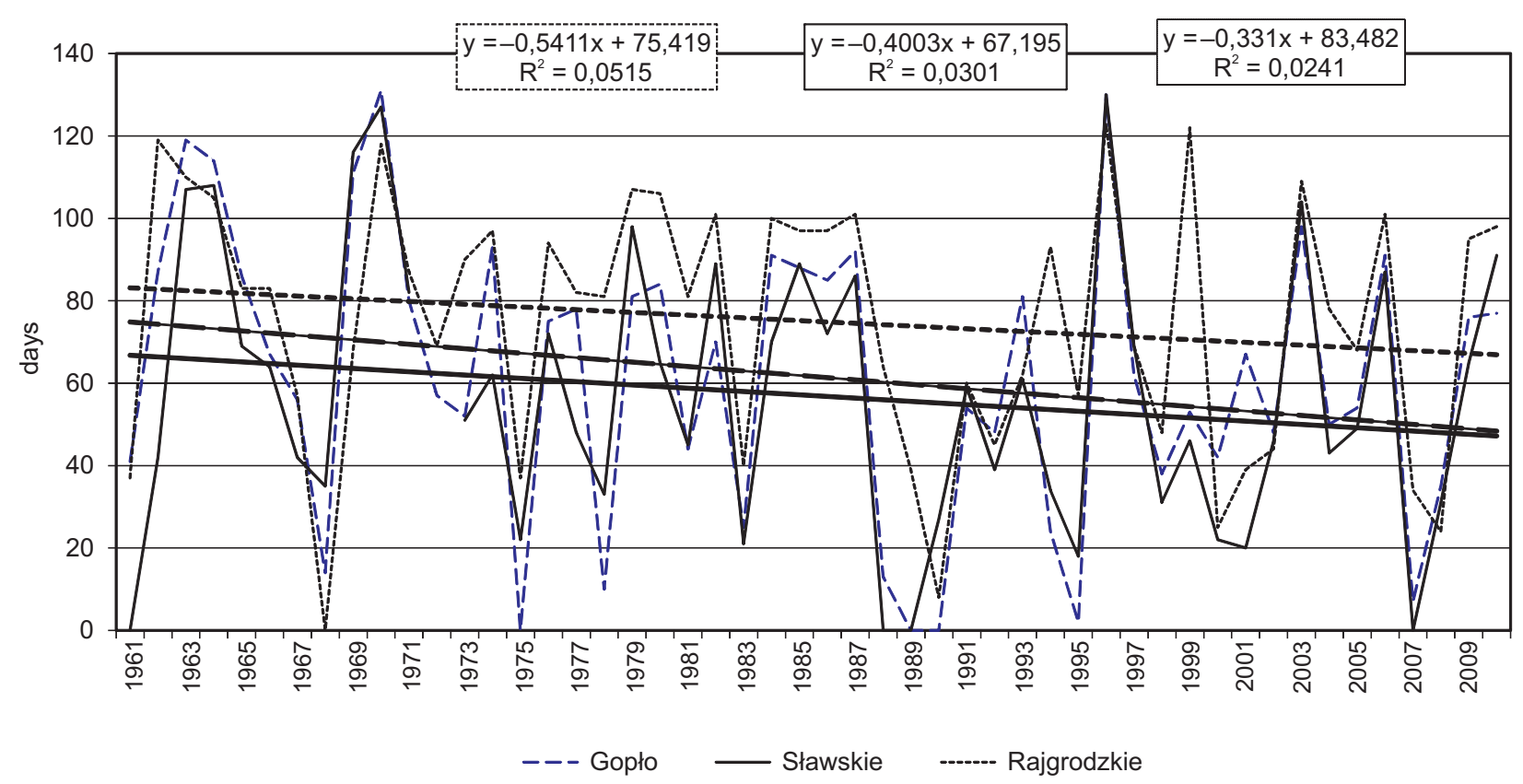

Fig. 3. Tendencies of change in the duration of ice cover

land. Between the different $\mathrm{NAO}_{\mathrm{DJFM}}$ stages, the difference in ice-cover duration amounts to about 40 days $(p<0.01)$. In a negative stage ice cover lasts 20 days longer than on average $(p<0.05)$, and in a positive stage, 21 days shorter than on average $(p<0.05)$.

In a negative $\mathrm{NAO}_{\mathrm{DJFM}}$ stage, the maximum ice-cover thickness is from $12 \mathrm{~cm}$ (Lake Sławskie) to $21 \mathrm{~cm}$ (Lake Rajgrodzkie) greater than in a positive stage, and its stability index is $22 \%$ and 3\% higher, respectively. In turn, the date of appearance of the maximum ice-cover thickness comes some 20 days later on lakes Sławskie and Rajgrodzkie and about 6 days later on Gopło.
Changes in the intensity of the North Atlantic Oscillation affect all the ice parameters except the starting dates. In a negative $\mathrm{NAO}_{\mathrm{DJFM}}$ stage, ice phenomena and ice cover end later and last longer, the maximum thickness of ice cover is greater, its date of occurrence is later, and the stability index higher than in a positive stage and under the average conditions.

The results obtained corroborate the finding of various analyses carried out so far (for different time intervals) concerning the pattern of ice phenomena in lakes of this part of Europe (Magnuson et al. 2000, Yoo, D'Odorico 2002, Karetnikov, Naumenko 2008). Also with reference to lakes in other

Table 4. Coefficients of correlation between ice parameters and $\mathrm{NAO}_{\text {DJFM }}$

\begin{tabular}{|c|c|c|c|c|c|c|c|c|c|c|}
\hline \multirow{2}{*}{\multicolumn{2}{|c|}{ Lake }} & \multicolumn{2}{|c|}{ Start of } & \multicolumn{2}{|c|}{ End of } & \multicolumn{2}{|c|}{ Duration } & \multicolumn{2}{|c|}{$\begin{array}{c}\text { Thickness of ice } \\
\text { cover }\end{array}$} & \multirow{2}{*}{$\begin{array}{c}\text { Stability } \\
\text { of ice } \\
\text { cover } \\
\text { [\%] }\end{array}$} \\
\hline & & $\begin{array}{c}\text { Ice phe- } \\
\text { nomena } \\
\text { [date] }\end{array}$ & $\begin{array}{c}\text { Ice } \\
\text { cover } \\
\text { [date] }\end{array}$ & $\begin{array}{c}\text { Ice phe- } \\
\text { nomena } \\
\text { [date] }\end{array}$ & $\begin{array}{c}\text { Ice } \\
\text { cover } \\
\text { [date] }\end{array}$ & $\begin{array}{c}\text { Ice phe- } \\
\text { nomena } \\
\text { [days] }\end{array}$ & $\begin{array}{c}\text { Ice } \\
\text { cover } \\
\text { [days] }\end{array}$ & $\begin{array}{l}\text { Max } \\
{[\mathrm{cm}]}\end{array}$ & Date & \\
\hline \multirow{2}{*}{ Sławskie } & $\mathrm{n}$ & 49 & 45 & 49 & 45 & 49 & 45 & 34 & 34 & 49 \\
\hline & $\mathrm{r}$ & 0.142 & 0.107 & $-0.619^{* * *}$ & $-0.566^{* * *}$ & $-0.545^{* * *}$ & $-0.689^{* * *}$ & $-0.492^{* * *}$ & $-0.309^{*}$ & $-0.368^{* *}$ \\
\hline \multirow{2}{*}{ Gopło } & $\mathrm{n}$ & 50 & 47 & 50 & 47 & 50 & 50 & 30 & 30 & 47 \\
\hline & $\mathrm{r}$ & 0.119 & 0.273 & $-0.643^{* * *}$ & $-0.510^{* * *}$ & $-0.573^{* * *}$ & $-0.706^{* * *}$ & $-0.522^{* * *}$ & -0.073 & $-0.357^{*}$ \\
\hline \multirow{2}{*}{ Rajgrodzkie } & $\mathrm{n}$ & 49 & 49 & 49 & 49 & 50 & 50 & 39 & 39 & 49 \\
\hline & $\mathrm{r}$ & -0.078 & -0.020 & $-0.601^{* * *}$ & $-0.619^{* * *}$ & $-0.347^{*}$ & $-0.491^{* * *}$ & $-0.574^{* * *}$ & $-0.440^{* *}$ & -0.203 \\
\hline
\end{tabular}

Correlations significant at: ${ }^{*} \mathrm{\alpha}=0.05,{ }^{* *} \mathrm{\alpha}=0.01,{ }^{* * *} \mathrm{\alpha}=0.001$ levels, $n$ - number of years, $r$ - correlation coefficient 
Table 5. Ice parameters in the different $\mathrm{NAO}_{\mathrm{DJFM}}$ stages and under average conditions; their differences and the test of the significance of the differences

\begin{tabular}{|c|c|c|c|c|c|c|c|c|c|}
\hline & $\begin{array}{l}\text { Start of } \\
\text { ice phe- } \\
\text { nomena }\end{array}$ & $\begin{array}{l}\text { Start of } \\
\text { ice cover }\end{array}$ & $\begin{array}{l}\text { End of } \\
\text { ice phe- } \\
\text { nomena }\end{array}$ & $\begin{array}{l}\text { End of } \\
\text { ice cover }\end{array}$ & $\begin{array}{c}\text { Duration } \\
\text { of ice } \\
\text { pheno- } \\
\text { mena }\end{array}$ & $\begin{array}{c}\text { Duration } \\
\text { of ice } \\
\text { cover }\end{array}$ & \multicolumn{2}{|c|}{$\begin{array}{l}\text { Thickness of ice } \\
\text { cover }\end{array}$} & \multirow{2}{*}{$\begin{array}{c}\begin{array}{c}\text { Stability } \\
\text { of ice } \\
\text { cover }\end{array} \\
\\
{[\%]}\end{array}$} \\
\hline & \multicolumn{4}{|c|}{ [Day of hydrological year] } & \multicolumn{2}{|c|}{ [Days] } & $\begin{array}{l}\text { Max } \\
{[\mathrm{cm}]}\end{array}$ & $\begin{array}{c}\text { [Day of } \\
\text { hydro- } \\
\text { logical } \\
\text { year] }\end{array}$ & \\
\hline \multicolumn{10}{|c|}{ Sławskie Lake } \\
\hline NAO- & 37.2 & 47.8 & 142.3 & 137.5 & 106.1 & 85.2 & 27.5 & 111.7 & 93.5 \\
\hline $\mathrm{NAO}+$ & 46.5 & 49.4 & 105.7 & 105.9 & 60.2 & 28.2 & 15.4 & 90.4 & 71.4 \\
\hline Mean 1961-2010 & 43.4 & 53.5 & 127.3 & 125.6 & 85.0 & 56.9 & 22.6 & 102.2 & 85.2 \\
\hline $\begin{array}{l}\text { Differences } \\
\mathrm{NAO}-\text { - NAO+ }\end{array}$ & -9.3 & -1.6 & 36.6 & 31.6 & 45.9 & 56.9 & 12.1 & 21.3 & 22.1 \\
\hline T-test & 1.24 & 0.20 & $4.46^{* * *}$ & $3.17^{* *}$ & $3.91^{* * *}$ & $5.15^{* * *}$ & 2.29 & 1.95 & $2.79 * *$ \\
\hline $\begin{array}{l}\text { Differences } \\
\text { NAO- - Mean }\end{array}$ & -6.2 & -5.7 & 15.0 & 12.0 & 21.1 & 28.3 & 4.9 & 9.5 & 8.3 \\
\hline $\mathrm{T}$ - test & 1.18 & 1.03 & $2.03^{*}$ & 1.56 & $2.16^{*}$ & $2.64^{*}$ & 1.02 & 0.97 & 1.45 \\
\hline $\begin{array}{l}\text { Differences } \\
\text { NAO+ - Mean }\end{array}$ & 3.1 & -4.1 & -21.6 & -19.7 & -24.7 & -28.7 & 7.2 & 11.8 & -13.8 \\
\hline $\mathrm{T}$ - test & 0.52 & 0.63 & $3.11^{* *}$ & $2.51^{*}$ & $2.57^{*}$ & $2.99 * *$ & 2.18 & 1.52 & 1.96 \\
\hline \multicolumn{10}{|c|}{ Gopło Lake } \\
\hline NAO- & 37.5 & 39.8 & 149.2 & 140.5 & 112.6 & 95.3 & 27.0 & 78.7 & 93.5 \\
\hline $\mathrm{NAO}+$ & 45.4 & 58.8 & 112.3 & 110.8 & 67.9 & 32.4 & 12.0 & 72.8 & 76.7 \\
\hline Mean 1961-2010 & 42.7 & 49.5 & 129.7 & 122.9 & 88.0 & 61.6 & 20.3 & 79.2 & 88.4 \\
\hline $\begin{array}{l}\text { Differences } \\
\mathrm{NAO}-\text { - NAO+ }\end{array}$ & -7.8 & -18.9 & 36.9 & 29.8 & 44.7 & 62.9 & 15.0 & 5.9 & 16.9 \\
\hline T-test & 0.90 & $2.35^{*}$ & $5.02^{* * *}$ & $3.82^{* * *}$ & $4.63^{* * *}$ & $6.69^{* * *}$ & 2.42 & 0.44 & 2.03 \\
\hline $\begin{array}{l}\text { Differences } \\
\text { NAO- - Mean }\end{array}$ & -5.1 & -9.7 & 19.5 & 17.6 & 24.6 & 33.7 & 6.7 & 0.6 & 5.1 \\
\hline $\mathrm{T}$ - test & 0.85 & 1.68 & $2.74^{* *}$ & $2.46^{*}$ & $2.66^{* *}$ & $3.26^{* *}$ & 1.21 & 0.06 & 0.99 \\
\hline $\begin{array}{l}\text { Differences } \\
\text { NAO+ - Mean }\end{array}$ & 2.7 & 9.2 & -17.4 & -12.1 & -20.1 & -29.2 & 8.3 & 6.5 & -11.7 \\
\hline $\mathrm{T}$ - test & 0.38 & 1.34 & $2.46^{*}$ & 1.58 & $2.17^{*}$ & $2.90^{* *}$ & 1.77 & 0.67 & 1.79 \\
\hline \multicolumn{10}{|c|}{ Rajgrodzkie Lake } \\
\hline NAO- & 56.4 & 59.1 & 157.4 & 153.2 & 102.0 & 95.1 & 41.8 & 119.8 & 100.0 \\
\hline NAO+ & 54.1 & 60.6 & 124.9 & 116.9 & 71.9 & 54.1 & 20.5 & 97.6 & 96.8 \\
\hline Mean 1961-2010 & 54.7 & 60.0 & 144.6 & 138.6 & 89.0 & 75.0 & 31.8 & 111.7 & 96.8 \\
\hline $\begin{array}{l}\text { Differences } \\
\mathrm{NAO}-\mathrm{NAO+}\end{array}$ & 2.3 & -1.6 & 32.5 & 36.3 & 30.1 & 41.0 & 21.3 & 22.2 & 3.2 \\
\hline T-test & 0.25 & 0.17 & $3.56^{* *}$ & $3.84^{* * *}$ & $2.36^{*}$ & $3.62^{* *}$ & 3.64 & 1.73 & 1.36 \\
\hline $\begin{array}{l}\text { Differences } \\
\text { NAO- - Mean }\end{array}$ & 1.6 & -1.0 & 12.8 & 14.6 & 13.0 & 20.0 & 10.0 & 8.1 & 3.2 \\
\hline $\mathrm{T}$ - test & 0.27 & 0.16 & 1.87 & $2.04^{*}$ & 1.32 & $2.13^{*}$ & 1.56 & 0.81 & 1.39 \\
\hline $\begin{array}{l}\text { Differences } \\
\text { NAO+ - Mean }\end{array}$ & -0.7 & 0.6 & -19.6 & -21.7 & -17.1 & -21.0 & 11.3 & 14.1 & 0.0 \\
\hline $\mathrm{T}$ - test & 0.10 & 0.09 & $2.57^{*}$ & $2.72 * *$ & 1.66 & $2.18^{*}$ & 2.64 & 1.80 & 0.01 \\
\hline
\end{tabular}

$\mathrm{T}$ - test of the significance of differences

regions of the world, e.g. the Great Lakes of North America (Bai et al. 2012), Siberia (Livingstone 1999) or Japan (Arai 2009), ice conditions have been found to depend on the NAO circulation.
Focusing on lakes located in Poland, Marszelewski and Skowron (2005) analysed the pattern of ice phenomena for six of them in the years 1961-2000. Among their findings was that the 
duration of ice phenomena had shortened over this period and that the thickness of ice cover had decreased.

Similar relations between ice parameters and NAO to those obtained in the present study were established by Girjatowicz (2003) for the coastal lakes on the southern shore of the Baltic. When examining four of them on the basis of the 19602000 data, he found that the relations between the NAO index and the start of ice phenomena were weaker than between the index and their end.

In a detailed analysis of the mean values of ice characteristics of Lakes Sławskie and Gopło, the results obtained were compared against those for the multi-year period 1961-2005 (Marszelewski, Skowron 2009). With data for a longer observation time (1961-2010), it was demonstrated, among other things, that the duration of ice cover had shortened over that time by 1.3 days in the case of Lake Sławskie and 4.1 days for Gopło.

\section{Conclusions}

The analysis of the ice parameters of the three selected lakes on the Polish Plain in the years 1961-2010 presented in the article usually reveals them to show a downward tendency. While changes in the date of the appearance of ice phenomena and ice cover are slight, those in the dates of their decay are substantial and often statistically significant. As a result, also the duration of ice phenomena and ice cover displays a downward trend. The thickness of ice cover and its stability tend to diminish as well. The ice regime of lakes is controlled not only by climatic conditions, but also by individual features of the lakes. An example is the date of the appearance of ice phenomena, which was the latest in the easternmost-lying Lake Rajgrodzkie, located in an area with the most strongly pronounced continental features of the climate. However, its basin also has the greatest capacity among the analysed water bodies. Therefore it takes longer for the larger amount of warmth it has accumulated to be released to the environment, and this means a later date of the appearance of ice on it.

The research has demonstrated, in the tests performed, that the ice parameters of the lakes are significantly affected by changes in the inten- sity of $\mathrm{NAO}_{\mathrm{DJFM}}$. In its negative stage, ice phenomena and ice cover disappear markedly later, can persist even two months longer, and the ice-cover stability is greater. Interestingly enough, with an increase in the continentality of the climate, which is the case of Lake Rajgrodzkie, the NAO stage-dependent differences in its ice characteristics are smaller than on the other lakes.

In view of the observed changes, climatic variations and their hydrological consequences, further studies of the ice regime of the lakes seem necessary and promise to be interesting. They should focus, e.g., on spatial differences in the changes in their ice parameters as connected with the intensity of macro-scale types of atmospheric circulation and individual characteristics of the lakes.

\section{References}

Bednorz E., 2009. Wptyw sytuacji barycznych na występowanie pokrywy śnieżnej na obszarach nizinnych środkowej Europy. Wydawnictwo Naukowe UAM Poznań, ser. Geografia 82.

Blenckner T., Järvinen M. \& Weyhenmeyer G.A., 2004. Atmospheric circulation and its impact on ice phenology in Scandinavia (Conference Paper). Boreal Environment Research 9(5): 371-380.

Bryś K., Bryś T., 2002. Wpływ Oscylacji Północnoatlantckiej na zmienność warunków wilgotnościowych, radiacyjnych, dynamicznych i ewaporacyjnych we Wrocławiu-Swojcu w latach 1946-2000. In: A. Marsz, A. Styczyńska (eds.), Oscylacja Pótnocnego Atlantyku $i$ jej rola w kształtowaniu zmienności warunków klimatycznych i hydrologicznych Polski. Akademia Morska w Gdyni, Gdynia: 147-160.

Choiński A., 2006. Katalog jezior Polski. Wyd. Nauk. UAM, Poznań.

Choiński A., 2007. Limnologia fizyczna Polski. Wyd. Nauk. UAM, Poznań

Choiński A., Gałka M., Ławniczak A.E., 2006. Przykłady zróżnicowania grubości pokryw lodowych wybranych jezior. Badania Fizjograficzne nad Polska Zachodnia, Geografia Fizyczna 57: 15-20.

Choiński A., Kolendowicz L., Pociask-Karteczka J., 2009. Zjawiska lodowe na Morskim Oku jako wskaźnik zmian klimatu w Tatrach. In: A.T. Jankowski, D. Absalon, R. Macowski, M. Ruman (eds.), Przeobrażenia stosunków wodnych w warunkach zmieniajacego się środowiska. Wyd. Wydziału Nauk o Ziemi UŚ: 71-77.

Choiński A., Ptak M., 2012. Variation in the ice cover thickness on Lake Samołęskie as a result of underground water supply. Limnological Review 3: 133-138.

Clifton W.J., 1875. Ice phenomena in the lake district. Nature. 11(277): 309-310.

Falarz M., 2007. Snow cover variability in Poland in relation to the macro- and mesoscale atmospheric circulation in 
the twentieth century. International Journal of Climatology. 27: 2069-2081.

Girjatowicz J.P., 2003. The influence of North Atlantic Oscillation on ice conditions in coastal lakes of the Southern Baltic Sea. Annales de Limnologie 39(01): 71-80.

Górniak A., Pękala M., 2001. Zjawiska lodowe jezior północno-wschodniej Polski (Ice phenomena on lasek In North-Estern Poland). Przeglad Geofizyczny 56(1-2): 91-111.

Grześ M., 1974. Badania nad termiką i zlodzeniem jeziora Gopło. Dokumentacja Geograficzna 3: 57.

Hurrell J.W., 1995. Decadal trends in the North Atlantic Oscillation: regional temperatures and precipitation. Science, 269: 676-679.

IMiGW, 1961-1983. Hydrological Yearbooks, Warszawa.

Kożuchowski K., Degirmendžić J., 2002. Wskaźniki cyrkulacji a temperatura powietrza w Polsce. In: A. Marsz, A. Styszyńska (eds.), Oscylacja Pótnocnego Atlantyku i jej rola w kształtowaniu zmienności warunków klimatycznych $i$ hydrologicznych Polski. Akademia Morska w Gdyni: 111128.

Livingstone D.M., 1997. Break-up dates of alpine lakes as proxy data for local and regional mean surface air temperatures. Climatic Change 37: 407-439.

Livingstone D.M., 1999. Ice break-up on southern Lake Baikal and its relationship to local and regional air temperatures in Siberia and to the North Atlantic Oscillation. Limnology and Oceanography 44(6): 1486-1497.

Livingstone D.m., Dokulil M.T., 2001. Eighty years of spatially coherent Austrian lake surface water temperatures and their relationship to regional air temperature and the North Atlantic Oscillation. Limnology and Oceanography 46: $1220-1227$.

Magnuson J.J., Robertson D.M., Benson B.J., Wynne R.H., L Aprilingstone D.M., Arai T., Assel R.A., Barry R.G., Card V., Kuusisto E., Granin N.G., Prowse T.D., Steward K.M., Vuglinski V.S., 2000. Historical trends inlake and river ice cover in the Northern Hemisphere. Science 289(5485): 1743-1746

Marsz A., 2001. Stan termiczny Pótnocnego Atlantyku a reżim termiczny zim na polskim wybrzeżu Battyku (problem długoterminowej prognozy termiki zim). Wyższa Szkoła Morska w Gdyni, 107 pp.
Marsz A., Styszyńska A., 2001. Oscylacja Północnego Atlantyku a temperatura powietrza nad Polską. Wyższa Szkoła Morska w Gdyni, Gdynia.

Marsz A., Żmudzka E., 1999. Oscylacja Północnego Atlantyku a długość okresu wegetacyjnego w Polsce. Przegląd Geofizyczny 44(4): 199-210.

Marszelewski W., Skowron R., 2006. Ice cover as an indicator of winter air temperature changes: case study of the polish Lowland lakes. Hydrological Science Journal 51(920): 236-349.

Niedźwiedź T., 2002. Relacje między NAO a wskaźnikami cyrkulacji nad Polską. In: A. Marsz, A. Styszyńska (eds.), Oscylacja Pótnocnego Atlantyku i jej rola w kształtowaniu zmienności warunków klimatycznych i hydrologicznych Polski. Akademia Morska w Gdyni: 87-97.

Pasławski Z., 1982. Zlodzenie jezior w Polsce. Przeglad Geograficzny 27(1-2): 79-92.

Przybylak R., Wójcik G., Marciniak K., 2003. Wpływ Oscylacji Północnoatlantyckiej i Arktycznej na warunki termiczne chłodnej pory roku w Polsce w XVI-XX wiekach. Przeglad Geofizyczny 48: 61-74.

Radziejewski M., Kundzewicz Z.W., 2002. Hydrospect - program do wykrywania zmian $w$ danych hydrologicznych. In: Z.W. Kundzewicz, M. Radziejewski (eds.), Detekcja zmian klimatu i procesów hydrologicznych. Wyd. Sorus, Poznań.

Skowron R., 2003. Ice sheet in the lasek of the Polish Lowland. Distribution, differences and trends. Limnological Review 3: 205-212.

Skowron R., 2011. Zróżnicowanie i zmienność wybranych elementów reżimu termicznego wody w jeziorach na Niżu Polskim. Wydawnictwo Naukowe UMK, Toruń.

Styszyńska A., 2001. Oscylacja Północnego Atlantyku a opady na obszarze Polski. Prace i Studia Geograficzne 29: 232-241.

Wibig J., 2001. Wptyw cyrkulacji atmosferycznej na rozktad przestrzenny anomalii temperatury $i$ opadów $w$ Europie. Wyd. Uniw. Łódz., 208 pp.

Yoo J., D'odorico P., 2002. Trends and fluctuations in the dates of ice break-up of lakes and rivers in Northern Europe: The effect of the North Atlantic Oscillation. Journal of Hydrology 268(1-4): 100-112. 